\title{
Phosphorus cycling in watersheds: from limnology to environmental science
}

\author{
Shin-ichi Onodera ${ }^{1}$ (D) Noboru Okuda ${ }^{2,3} \cdot$ Syuhei Ban $^{4} \cdot$ Mitsuyo Saito $^{5} \cdot$ Adina Paytan $^{6} \cdot$ Tomoya Iwata $^{7}$
}

Received: 12 June 2020 / Accepted: 15 June 2020 / Published online: 18 July 2020

(C) The Japanese Society of Limnology 2020

The international special session "A-HW20: Materials transport and nutrient cycles in watersheds; Human and climate impacts" of Japanese Geoscience Union (JpGU) Meeting 2018 was opened on May 20-21 in 2018 in Chiba in collaboration with the American Geophysical Union (Saito et al. 2018). In this session, 17 presentations focused on phosphorus cycling in watersheds out of a total of 51 presentations, and interdisciplinary discussions were carried out by researchers representing various fields including limnology, hydrology, geology, ecology, soil physics, civil engineering, oceanography and more. Based on these presentations and discussions, phosphorus transport processes and fluxes and their impact by human activity and climate change on a watershed scale were summarized. The other articles focused on material transport and cycle were published in

Handling Editor: Ichiro Tayasu

Shin-ichi Onodera

sonodera@hiroshima-u.ac.jp

1 Graduate School of Advanced Science and Engineering, Hiroshima University, Kagamiyama, Higashi-Hiroshima 739-8521, Japan

2 Research Institute for Humanity and Nature (RIHN), 457-4, Motoyama, Kamigamo, Kyoto 603-8047, Japan

3 Center for Ecological Research, Kyoto University, 2-509-3, Hirano, Otsu, Shiga 520-2113, Japan

4 Department of Ecosystem Studies, School of Environmental Science, The University of Shiga Prefecture, 2500 Hassaka-cho, Hikone, Shiga 522-8533, Japan

5 Graduate School of Environmental and Life Science, Okayama University, 3-1-1 Tsushima-naka, Kita-ku, Okayama 700-8530, Japan

6 Institute of Marine Sciences, University of California Santa Cruz, 1156 High St, Santa Cruz, CA 95064, USA

7 Faculty of Life and Environmental Sciences, University of Yamanashi, 4-4-37, Takeda, Kofu 400-8510, Japan another special feature named "Material transport and cycle in watersheds".

Phosphorus is one of the limiting elements for primary productions in lakes and the reason for ongoing eutrophication despite the reduction measures being a limnological research paradigm (Sterner 2008). Phosphorus generally cycles extensively within an individual ecosystem such as forest, inland water, wetland, and marine, but the flows from the internal to the external ecosystem and from the terrestrial area to the ocean with hydrological processes are extremely small (Paytan and McLaughlin 2007). However, human and climate impacts on the phosphorus cycle within various ecosystems have caused an increase in phosphorus concentrations due to internal or external sources with considerable consequences to freshwater, marine, and terrestrial ecosystems (Elser et al. 2007). This includes biodiversity loss, soil degradation, eutrophication in watersheds, hypoxia and more (Rockström et al. 2009). To mitigate and reduce the environmental issues, it is important to better constrain the phosphorus cycle in watersheds by specifically considering the connectivity between terrestrial, freshwater, and marine ecosystems. Recently, new approaches for shedding light on the phosphorus cycle have been developed such as isotopic techniques, XANES, and NMR and new knowledge has been accumulated (Paytan et al. 2017).

This special issue includes eight manuscripts that collectively aimed to synthesize watershed sciences to understand the dynamic processes of phosphorus cycle and transport in watersheds from headwaters to coastal seas focusing on human and climate impacts. Yi et al. (2020) clarified how the spectrophotometrical measurement overestimated actual phosphate concentrations in shallow lakes, using ion chromatography. Ide et al. (2020) compared the oxygen isotope ratio of dissolved phosphate $\left({ }^{18} \mathrm{O}-\mathrm{PO}_{4}{ }^{-}\right)$in two rivers with different land cover and geological features within Lake Biwa basin, to explore which factor primarily controls the oxygen isotope ratio of dissolved phosphate. These two 
papers focus on assessing the utility of novel methodologies for the study of phosphorus transport and cycling in watersheds. Iwata et al. (2020) applied a recently developed Lagrangian approach to the sixth-order Fuji River to identify seasonal dynamics of in-stream uptake rates for inorganic nitrogen and phosphorus by tracking a specific water parcel along the river course. This new modeling approach is powerful for comparing biochemical activities in various watersheds. Ishida et al. (2020) confirmed the effects of winter flooding on reducing phosphorus loads in rice fields by coprecipitation of phosphorus with iron. Shimizu et al. (2020) looked at small stream impoundment effects on phosphorus and nitrogen dynamics in a suburban watershed. These two papers identified unique processes of phosphorus capture in rice fields during winter flooding and river impoundments, respectively. Jin et al. (2020) explained phosphorus cycling in sediments of a nutrient-rich embayment with emphasis on sediment phosphorus pool and release. Muta et al. (2020) indicated that annual nutrient fluxes from the sediment were comparable to those from terrestrial areas in a semienclosed bay. Both papers highlight the active phosphorus cycling between the water body and sediment in coastal areas. Matsuoka et al. (2020) examined the effects of composted aquatic plants application on richness and composition of soil bacterial assemblages responsible for alkaline phosphatase production, information which is relevant for the phosphorus recycling in eutrophic lakes and agricultural land.

We hope the papers in this special volume of "Limnology" will evolve and integrate research on the phosphorus cycle in watersheds and will serve to solve environmental issues in watershed science. We thank each of the reviewers and editors for their suggestions and comments which improved the papers. Most of the papers published in this feature were supported by the RIHN (Research Institute for Humanity and Nature) Project (D06-14200119; PI: Okuda N).

\section{References}

Elser JJ, Bracken MES, Cleland EE, Gruner DS, Harpole WS, Hillebrand H, Ngai JT, Seabloom EW, Shurin JB, Smith JE (2007) Global analysis of nitrogen and phosphorus limitation of primary producers in freshwater, marine and terrestrial ecosystems. Ecol Lett 10(12):1135-1142. https://doi.org/10.111 1/j.1461-0248.2007.01113.x
Ide J, Ishida T, Cid-Andres AP, Osaka K, Iwata T, Hayashi T, Akashi M, Tayasu I, Paytan A, Okuda N (2020) Factors characterizing phosphate oxygen isotope ratios in river water: an inter-watershed comparison approach. Limnology 21:365-377. https://doi. org/10.1007/s10201-020-00610-6

Ishida T, Uehara Y, Ikeya T, Haraguchi TF, Asano S, Ogino Y, Okuda $\mathrm{N}$ (2020) Effects of winter flooding on phosphorus dynamics in rice fields. Limnology 21:403-413. https://doi.org/10.1007/s1020 1-020-00621-3

Iwata T, Ikeda Y, Uzawa R, Ikarashi Y (2020) Lagrangian tracking measurements revealed the temporal dynamics of nitrogen and phosphorus spiralling in a large Japanese river. Limnology 21:379-391. https://doi.org/10.1007/s10201-020-00612-4

Jin G, Onodera S, Saito M, Shimizu Y (2020) Sediment phosphorus cycling in a nutrient-rich embayment in relation to sediment phosphorus pool and release. Limnology 21:415-425. https:// doi.org/10.1007/s10201-020-00627-x

Matsuoka S, Fujinaga S, Kobayashi Y, Hobara S, Osono T (2020) Bacterial 16S rDNA and alkaline phosphatase gene diversity in soil applied with composted aquatic plants. Limnology 21:357-364. https://doi.org/10.1007/s10201-019-00594-y

Muta N, Umezawa Y, Yamaguchi A, Suzaki H, Wada M, Nakata H, Kawamoto K, Matsuoka K (2020) Estimation of spatiotemporal variations in nutrient fluxes from sediments in the seasonally hypoxic Omura Bay, Japan. Limnology 21:341-356. https://doi. org/10.1007/s10201-019-00591-1

Paytan A, McLaughlin K (2007) The oceanic phosphorus cycle. Chem Rev 107:563-576

Paytan A, Roberts K, Watson S, Peek S, Chuanga P-C, Defforey D, Kendall C (2017) Internal loading of phosphate in Lake Erie Central Basin. Sci Total Environ 579:1356-1365

Rockström J, Steffen W, Noone K, Persson A, Chapin FS, Lambin EF, Lenton TM, Scheffer M, Folke C, Schellnhuber HJ, Nykvist B, de Wit CA, Hughes T, van der Leeuw S, Rodhe H, Sörlin S, Snyder PK, Costanza R, Svedin U, Falkenmark M, Karlberg L, Corell RW, Fabry BJ, Hansen J, Walker B, Liverman D, Richardson K, Crutzen P, Foley JA (2009) A safe operating space for humanity. Nature 461:472-475

Saito M, Onodera S, Hosono T, Paytan A (2018) Materials transport and nutrient cycles in watersheds; human and climate impacts. In: Japanese geoscience union meeting 2018 A-HW20. http://www. jpgu.org/meeting_2018/SessionList_jp/detail/A-HW20.html

Shimizu Y, Onodera S, Jin G, Saito M (2020) Effect of in-stream impoundment on water quality of a suburban stream. Limnology 21:393-402. https://doi.org/10.1007/s10201-020-00619-x

Sterner RW (2008) On the phosphorus limitation paradigm for lakes. Int Rev Hydrobiol 93:433-445

Yi R, Song P, Liu X, Maruo M, Ban S (2020) Differences in dissolved phosphate in shallow-lake waters as determined by spectrophotometry and ion chromatography. Limnology 21:329-339. https ://doi.org/10.1007/s10201-019-00574-2

Publisher's Note Springer Nature remains neutral with regard to jurisdictional claims in published maps and institutional affiliations. 